\title{
LEARNING MANAGEMENT SYSTEM IN HIGHER EDUCATION: AN EXPERIENCE AT MELBOURNE UNIVERSITY
}

\author{
Kasinyo Harto \\ Faculty of Tarbiyah | State Institute for Islamic Studies Raden Fatah Palembang, Indonesia \\ Email: masyo_71@yahoo.com
}

\begin{abstract}
Abstrak
Pola pembelajaran pendidikan tinggi Islam, khususnya di Indonesia, umumnya didominasi pembelajaran konvensional dengan pendekatan yang berpusat pada guru di mana proses pembelajaran berfokus pada jalannya kuliah, bukan pada mahasiswa. Akibatnya, mahasiswa cenderung pasif dan miskin kreativitas, kurang mampu mendebat, mengujicoba, dan memahami ilmu pengetahuan. Melihat kenyataan ini, maka upaya-upaya ke arah rekonstruksi pola pembelajaran menjadi suatu keharusan. Salah satunya adalah melakukan tolok ukur dengan perbandingan terhadap perguruan tinggi di Australia, seperti Universitas Melbourne. Dengan demikian, penelitian ini berfokus pada sistem manajemen pembelajaran di Universitas Melbourne dalam kaitannya dengan pengembangan kualitas pembelajaran. Hasil penelitian menunjukkan bahwa strategi pembelajaran yang dikembangkan di Universitas Melbourne dapat meningkatkan pembelajaran aktif mahasiswa melalui berbagai pengalaman belajar, seperti diskusi on-line (pembelajaran kolaboratif), bacaan mingguan, ujian mingguan, tugas mingguan (belajar mandiri), presentasi kelas, dan diskusi meja bundar. Selain itu, sistem manajemen pembelajaran di Universitas Melbourne telah berjalan dengan baik seiring dengan sistem terpadu ICT di mana dosen dapat mengkomunikasikan programnya dan mahasiswa dapat berinteraksi dinamis dengan tugas, kuliah, dan mahasiswa lain. Diharapkan hal ini dapat menjadi inspirasi dan model alternatif bagi lembaga pendidikan tinggi Islam di Indonesia dalam merancang pola belajar mereka dan dalam menciptakan lingkungan untuk mendorong pembelajaran aktif.
\end{abstract}

Keywords: Pembelajaran, Manajemen, sistem, pendidikan tinggi

\begin{abstract}
Learning pattern of Islamic higher education, especially in Indonesia, is generally dominated by conventional learning with teacher-centered approach in which learning process focuses on the lectures, not on the students. As a result, the students tend to be passive and poor of creativity, less capable of arguing, trying, and appreciating science. Considering this reality, it is a necessity to make some efforts of reconstructing that learning pattern. One of them is doing bench-marking against universities in Australia, like Melbourne University. Therefore, this study focuses on learning management system of Melbourne University in relation to the development of learning quality. The result of the study shows that learning strategy developed at Melbourne University enhances student active learning through a variety of learning experiences, such as on-line discussion (collaborative learning), weekly readings, weekly exams, weekly assignments (independent learning), class presentation, and round table discussion. In addition, learning management system at Melbourne University has been running well along with an integrated system of ICT that enables the lecturers to communicate their courses and enables the students to interact dynamically with the tasks, lectures, and other students. It is expected that this can be an inspiration and alternative model for Islamic higher education institutions in Indonesia in designing their learning pattern and environment to promote active learning.
\end{abstract}

Keywords: Learning, Management, system, higher education 


\section{INTRODUCTION}

Learning patterns at public and private Islamic higher education like in UIN, IAIN, STAIN, and STAIS factually and historically still use teacher-centered in which learning process focuses on the teacher. Output of this learning approach only makes students who do not have ability to appreciate science and are not brave to express their ideas. Finally, teacher-centered makes students passive and lack of creativity. We often see these students in classrooms at Islamic higher education.

Teacher-centered approach was built based on banking learning concept. This concept tends to put students as a bank and teacher as a person who deposit his money. Dichotomy of banking learning concept always contrasts between position of teacher and students. In this approach, if a teacher gives a lecture, students listen, if a teacher asks, students answer, if a teacher know all, students know nothing, if a teacher dictate, students take note, if a teacher is clever, students are stupid, if a teacher is a subject of fund, students is an object, if a teacher makes learning program, students accept the program, and so on. In other words, learning process as Freire called Banking System is started from the assumption that students is like a blank paper. Teacher should fill or write on that paper (Freire, 1999).

This concept leads to form one way learning model, anti-dialogue and anti-critic. A teacher is superior and students are inferior. Asking teacher questions gives chance to break the truth according to the teacher. This situation leads to culture of silent.

Nowadays, this concept has been left behind because there is a strong awareness in educational world that teaching and learning process will be more effective if students actively experience, understand, and learn from their experiences. The result of learning process becomes part of students' feeling, thought, and experience. Its influence, the result of learning process will easily be remembered by the students. In this process, the students are motivated and conditioned to be more creative.

This new awareness is considered more human because students as a blank paper will not be seen anymore. This view considers the students have experience, knowledge, feeling, ambition, joy, and skills. Therefore, student's experience should be appreciated and it can be inserted in learning process. It implies that interactive learning strategy is needed not only among students but also between teacher and students.

Today, phenomenon appearing in the classrooms at Islamic higher education institution is still generally described as conventional learning patterns. A new awareness as described in previous paragraph has not touched the whole students. There are so many teachers who do not have ability to apply various active learning methodologies to make students active. To see this fact, the writer thinks that it is possible to make steps of improvement of learning patterns. One of the ways is by doing bench-marking toward higher education in Australia, such as University of Melbourne.

University of Melbourne was chosen as a basis of this writing because of two reasons. Firstly, University of Melbourne has the first rank in Australian rank and world rank. The success of this university in world rank university is because of social, cultural, biomedical fields of studies. The writer thinks the popularity of those fields of studies are supported by a verygood learning system so that they make good output, not only the product of learning but also the alumni. Secondly, the writer had chance to visit this university to observe teaching and learning process directly. With these two reasons, the writer would like to explore learning management system developed in this university. The result of this study is expected to be an alternative developing model of learning management system for teaching at Islamic higher education to improve performance of educational quality. 
Based on the background above, the problems of this study are as follows: 1) How are the learning patterns at University of Melbourne? 2). What are the appropriate recommendations for Islamic Higher Education (PTAI) as an effort to develop learning management in relation with learning management context of University of Melbourne?

\section{Objectives of The Study}

This study has theoretical and practical objectives. This study theoretically states that learning process with student-centered will give students more learning opportunities than conventional concept, Bank System. This study can practically be learnt by teachers, mainly at Islamic Higher Education (PTAI) to improve their ability in appreciating students and to give students more opportunities to explore themselves in learning process.

\section{Library Research}

Learning with student-centered pattern has become a mainstream in education since Paulo Freire in 1990s published his book about the critic on education which does not give freedom. In line with what Friere said, there are monumental books appeared. Some of them are Beyond Teaching and Learning (1992) written by Win Wenger, Active Learning (1996) written by Mel Silberman, Quantum Learning and Quantum Teaching (1999) written by Bobbi dePorter, Multiple Intelligence (1983) written by Howard Gardner, Accelerated Learning (1978) written by Georgi Lozanov, and Contextual Teaching and Learning (2002) written by Elaine B Jhonson. These books are good to be used, either in high education or basic and middle education because of positive inspiration in building learning management based on student-centered.

Studies on learning management system are often discussed in articles of journal Active
Learning in Higher Education published by Sage Publisher in electronic journal alh.sagepub. com. Generally, studies appeared in this journal has something to do with active learning at many universities and schools. The application of various interactive models and new findings about pleasant and effective learning becomes a main focus for the researchers. Some studies talked about learning patterns at higher education are Learning to Teach in Higher Education (1992) by P. Ramsden, Tools for Teaching (1993) by Barbara Gross Davis, The Art of Teaching Adults (1994) by Peter Renner, Teaching Tips (1994) by Wilber J McKeachie, Student Centered Teaching: The Development and Use of Conceptual Frameworks (1996) by Kym Fraser, and Adult Learning (1997) by Peter Sutherland.

From the studies above, the writer does not specifically find learning management discussed by the researchers. The writer thinks that those studies are very important as dialogue and analysis to enrich the writer's study. Thus, this study is different from the previous studies and it can give contribution for the development of educational management studies, mainly for Islamic Higher Education in Indonesia.

\section{Literature Review}

Theoretical framework of this study is about learning management system which started from active learning done in University of Melbourne. That's why this study will be focused based on active learning paradigm socialized by Silberman.

In his inspirational book, Silberman (1996) introduced the advantages of active learning. He stated that learning will be more meaningful and useful if students use their all sense; ears, eyes, and think to analyze the information, and do something. In contrast, learning by using only one sense (for example, ear for listening) is not effective. There are some reasons why people tend to forget what they listen. One of 
interesting reason is correlated with number of words pronounced by a lecturer and students' ability in listening. Most lecturers pronounce one hundreds to two hundreds words per minute. Number of words listened by students depends on how they listen. If students listen with full concentration, they can listen fifty to one hundreds words per minute or at least half of lecturer's words because they are thinking while listening. The other reasons why students' understanding are not maximal because lecturer's tone is too slow or too fast, the material is not interesting, the atmosphere in the classroom is not conducive, etc.

Result of study showed that students in classroom can pay attention and fully concentrate more or less $60 \%$ from time allocated (Polio:1984). Then, students can remember $70 \%$ material presented in first ten minutes. In last ten minutes they can remember $20 \%$ information from the presented material (McKeachie:1986).

Other study showed that learning process put students only as listeners will make the following problems: 1) Students' attention will be less as time goes by. 2) It is only interesting and appropriate for auditory students. 3) It tends to lead to low learning level from factual information. 4) Students do not prefer to it. 5) It assumes that students need the same information at the same steps (Jhonson and Smith,1992).

By adding visual element on the lesson, students can increase their memory from $14 \%$ to $38 \%$. This study also indicated $200 \%$ improvement when vocabularies were taught by using visual media (Pike,1989). Even, time needed to convey the concept was reduced until $40 \%$ when unsure visual was used to add verbal presentation. If unsure auditory and visual are collaborated with unsure kinesthetic, the learning will obtain the best result as stated by Confusius, China philosopher who lived more that 2400 year s ago and became active learning credo as cited by Silberman:

What I hear, I forget
What I hear and see, I remember a little

What I hear, see, and discuss, I understand

What I hear, see, discuss, and do, I obtain knowledge and skills

What I teach others, I master

\section{DISCUSSION}

\section{Learning Management System At Melbourne University: An Observation}

University of Melbourne is the second oldest university in Australia, located in Melbourne, Victoria Australia. The main college is located at Park Ville, Northern area of Melbourne. It is ranked as the first university in social, cultural, and biomédical fields of study in the world and in Australia. It has almost 40.000 students and 6.000 staffs. In November 15, 2005, Vice-Chancellor Glyn Davis announced new program named Growing Esteem. The program provides 3 main activities; research, learning, and transfer knowledge in order to be the best institution in the world. The former graduation structure started to be changed into Melbourne Model, the combination from American and European model. It is in line with Bologna MOU that guaranties the alumni have international standard skill (Observation: 3 November 2010).

The achievement of University Melbourne as first university can be seen from the output. University of Melbourne has the target that the alumni must have some skills, such as:

Pertama, academic excellence. At this point, the alumni are expected to have strong intellectual integrity and deep scientific ethics. They have to have deep knowledge accordance with their major, reach the highest level of writing, do the generic research, and have communication ability in problem solving. Included in characteristics of academic excellence, the alumni can be proportional thinkers and practitioners and learn continuously. 
Kedua, knowledgeable across disciplines. The explanation of this point is that the graduates have to 1) have ability to test critically and synthetically, and see the knowledge in wide discipline, 2) develop analytical ability and cognitive skill through learning experiences of different subjects, 3) have capacity which fully involved in collaborative learning and confront the latest issues, 4) have a set of flexible skills and abilities which can be transferred into different working fields.

Ketiga, leaders in communities. The alumni are expected to 1) have initiative and constructive implementation of changes in communities including in profession and appropriate job, 2) have interpersonal excellence and skills in decision making including awareness of self strengths and weaknesses, 3) become advisor for the next learners, 4) be meaningfully involved in public context with deep awareness of communities needs.

Keempat, ability in accepting various culture by being alumni who 1) have value different culture, 2) be well-informed citizens who are able to contribute to their communities wherever they choose to live and work, 3) have an understanding of the social and cultural diversity in community, 4) respect indigenous knowledge, cultures and values.

Kelima, active global citizen. University of Melbourne realizes that its alumni will be take part globally that is why the alumni 1) accept social and civic responsibilities, 2) be advocates for improving the sustainability of the environment, 3) have a broad global understanding, with a high regard for human rights, equity, and ethics.

A very high target of alumni above becomes a reason for the writer to see how contributive the learning management system produces students of University of Melbourne so they have competences above. Based on direct observation, it was found out that University of Melbourne applied learning management system thoroughly, that is an integrative system enables the whole students be able to interact dynamically with assignments, other students, and lecturers. This system can be defined as a set of curriculum which can develop active learning through collaborative and independent learning. As a set of curriculum, this system should use technology used by the lecturers in their learning approach.

This learning management system appears in learning circles correlated to one another. Therefore, teaching and learning in University of Melbourne develops learning model based on active learning emphasizing inquiry method (discovery) and constructivism (an active process in which students use their thought to build understanding). ${ }^{1}$

Learning process is started from wellprepared lecturers' planning. It can be seen from instructional design made by the lecturers. At first, lecturers made learning objectives that should be achieved. Then, lecturers determine learning topics developed in a form of teaching material, references, assignments, scoring system. In its application, the learning can be done through three steps: attendance, lecture, and independent learning.

The first is attendance in classroom. This pattern is a routine meeting between lecturer and students in classroom in a form of dialogue communication. In this step, a lecturer shares knowledge and facilitate the learning in a form of class discussion by exploring ideas and clarifying ambiguous answers. To motivate students to be active in learning process, every lecturer gives them opportunities to ask questions and discuss the topic. Every lecturer at each study program applies active learning so it gives students more chances to participate in classroom. Students' involvement in this learning process is reflected from the average of their $75 \%$ attendance. In addition, students'

${ }^{1}$ Interview with Steve Campitelli, Roger Hurcomber, Karen Dacy, staff of Learning System Management, the writer's advisors during the observation from November 1 to December $1,2010$. 
attendance at the library is compulsory. It can be seen from the loan of the books. It is caused by the students' need in doing assignment that uses actual references.

After class discussion, the learning process can be continued to tutorial session (the second step). In this step, the discussion is done in small groups out of classroom and led by a senior student chosen by the lecturer which is usually taken from graduate program. The purpose is to reinforce and study the material further through group discussion. Online discussion is another way to interact between lecturer and student. Here, the students do collaborative learning and independent learning in well prepared learning space on university corners. Further, students will continue the activity in weekly exam, weekly reading, and weekly assessment through class presentation and roundtable discussion. The whole learning process is done strictly by obeying the rule, at least $75 \%$ attendance.

To support the learning circle, University of Melbourne uses technology as a vital media to develop active learning through dynamic interaction between lecture and students. Therefore, the learning interaction among lecturer and students whether through face to face in classroom or internet link at Melbourne University will be done using modern high technology software and hardware that make both lecturer and students feel no more limitation to do the active learning. All classes are supported by LCD Projector and computer which can access learning references such as libraries in Melbourne University and other universities. Moreover, Information media will be found in all academic rooms such as laboratory, libraries, lecturers' and staffs' office, hall, even in kitchen which is integratedly controlled by main office of information and technology at Melbourne University.

To add academic impression, the following information can be a proof how learning systems in Melbourne University support each other from landscaping, architect, and usage.
University area is open area for transport access for all citizens in town. In university area, all learning facilities are available for the students. Teaching and learning process and researches are done in modern Victorian-style buildings. A library, as a heart of university provides various rooms with different functions are equipped by digitals and sophisticated equipment. Students do their activities in those rooms. In discussing room, students discuss their assignment. In reading room, students with forty four backgrounds and different races read the books silently. On information desk, librarians are friendly to serve the visitors. If the students have assignments from their lecturer, they do not have difficulties finding references.

Formal learning process also happens out of classroom. With agreement, lecture and students can interact and transfer knowledge at café or other comfortable places to discuss the lessons. The lecturer's willingness serving the students to create conducive academic atmosphere can be done through internet. Lecturers often give assignment through websites, and email which contains learning material. It enables the students to open their email everyday.

Learning process can also be done not only in local but also international seminars. University of Melbourne has cooperation with sponsor to held seminar, symposium, or activities which supporting to create conducive academic atmosphere. Among famous universities, University of Melbourne is known as an outstanding university in developing researches so it becomes the highest ranked university and it is productive because it can sell the products of the results of the researches, especially the advantages of technology.

The support that is also important in learning management system in University of Melbourne is information system. Information system is as an existence, procedure, method and strategy and function patterned and 
implanted to develop access to gain, manage, collect, transfer data, and information needed to reach institutional objectives effectively and efficiently. Information system of University of Melbourne contain all database concerning with the university. As long as anyone or any institution follows the rules, they can see and access through university website. However, there are some data which are protected by the university and it can be accessed by using password. Beside technological information system, University of Melbourne still use manual system for specific information. Information board can be found at some building corners but the users of this system are mostly outsiders, for example, book publisher or information from other universities.

This learning cannot be separated from quality control system. University of Melbourne applies some quality controls, external, internal, and teaching quality control. Learning quality control is given at the end of semester trough student feedback questionnaire done by the students towards their lecturers.

\section{Implementation of Learning Management System In Islamic Higher Education In Indonesia}

\section{Mainstreaming Active Learning}

As discussed above, University of Melbourne uses the whole learning system management, an integrated system which enables all students to actively interact with lecturer and other students in doing assignments. This system can be defined as equipment that develops active learning through collaborative learning and self study.

Based on the definitions, it can be said as interactive parts which functionally makes input as the output. All parts of learning in University of Melbourne such as lecturers, students, learning references, have done the right way to prepare the input as competent output.
The system has characteristics as a) having purpose, b) having function to reach the goal, c) having components to do the functions, d) having integrated interaction among components, e) having unity, f) having transformation process, g) having feedbacks for improvements, and h) having area. Every system has purpose which is the goal of every event.

The general purpose of students' learning in University of Melbourne is to gain knowledge and improve understanding (cognitive aspect), develop scientific character (affective aspect) and improve analysis skill and problem solving (psychometric aspect).

Therefore, learning system management in University of Melbourne has brought a dynamic interactive concept to enable students interact by using inquiry and constructivism method based on ICT learning. In this part, why inquiry method is important method in University of Melbourne will be explained. Inquiry method is a set of learning activities that involve all students' capabilities to seek and analyze systematically, critically, analytically in order to formulate their own discoveries confidently. Therefore, lecturer will no longer function as the master of information and the students as the recipients, even though it is really important. The lecturer will function as motivator, facilitator, assessor, administrator, manager, and rewarder. Thus, the lecturer must analyze students' abilities, especially students' mindset, response and other aspects to function the lecturers' role effectively. As Usman (1993:124) defines the inquiry method as the process of transferring lesson by understanding something through critically, analysis and argumentative (scientific) by certain steps to conclude the information.

This method contrasts with a common opinion that students as an object and subject in learning process has basic ability to develop optimally based on their own abilities. A learning process should be seen as a stimulus which can challenge students to do learning 
activities. Lecturer's roles are focused as advisor, leader, and facilitator in learning process. Therefore, learners will do more selfstudy or group-study to solve problems with lecturer's guidance.

Another role of lecturer is to provide learning resources for students in problem solving. Teacher's guidance and supervision are still needed but lecturer's interruption in problem solving needs to be reduced.

Based on the explanation above, it can be said that this method focuses on students but lecturer still has an important role as learningexperience designer, guidance and resource of data information needed by the students.

Therefore, the most important thing from inquire learning process is students' involvement in every active learning process. In active learning, students can interact in small group or large group not only in designing assignment but also determining assignment procedures. It is conducted in free risk environment with high responsibility.

Active learning is now a current issue in learning method, not only in high education but also in school. Therefore, it is a must to do active learning in Islamic higher education. Dominant role of a lecturer should be decreased to enable learners gain the learning goals.

Active learning is a set of comprehensive learning strategies which involve various ways to make learners active since the early stages through activities in groups and make them think of the lesson in a short time. Besides, there are leadership strategies for all classes and small groups, attract learners to discuss and debate, apply skills, motivate learner to ask questions, even make learners to compete to each other.

Active learning is really needed by the students to gain maximum result of study. Passive learners will tend to forget the lesson easier. Therefore, a lecturer needs to find out new ways to keep the information given to the learners longer. Active learning is an alternative way to save information in learners' mind and find out the difficult answers given by the teacher

Based on the experience of university of Melbourne in applying the learning management system, it is then concluded that learning approach based active learning focused on enquiry and constructive methods have given important contribution for University of Melbourne, besides complete ICT and modern facilities. This system makes University of Melbourne as one of world class university in Australia and in the world.

It contrasts with Islamic higher education inIndonesia. Infact, the classroom arrangement describes the conventional learning system. Only few lecturers in Islamic higher education use active learning during the learning process. It is caused by lecturers' lacking of skills to apply the various learning methodology which can activate the learners. Thus, the writer thinks that it is possible to apply the active learning in Islamic higher education academic environment. If the application of active learning is done massively, the problems of adopting learning management system at Universitas Melbourne will be easier and it can strengthen the output quality performance.

\section{Adopting Learning Management System in University of Melbourne}

As it is explained above that learning management system in University of Melbourne looks like bounding learning cycle. Therefore, teaching and learning process in University of Melbourne develops learning model based on active learning by focusing on inquiry and constructive methods.

System as a set of items which interacts functionally shows that the unity of every item is the same as the learning management system. The university stakeholder is responsible to hold the educational process by providing competent human resources, complete facilities, and a conducive academic environment. It is hoped that $20 \%$ allocation 
from APBN can complete all facilities needed by all educational institution in Indonesia. However, human resources still have important role. It is why the process of adopting the learning management system can be begun by improving human resource quality in every higher education institution, which means the lecturers. If the lecturers have good competence, all barriers can be solved through various creativities which enable the transformation process of learning management system as it is done in Melbourne University.

As it is cited in the regulation of teacher and lecturer, point $1 \mathrm{UU}$ RI, lecturer is defined as a professional educator whose main jobs are to educate, teach, guide, train, asses, and evaluate the learners in higher education. The label 'professional educator' means multi translations when we relate it to the requirements of being a lecturer. It is discussed in chapter IV, article 8 UU RI No. 14, 2005 that a lecturer must be qualified academically, competent, get professional educator certificate, in well health condition, has the ability to gain the national education goals.

A lecturer is claimed to be competent if s/ he has some competences; be knowledgeable, be skillful, and has good attitudes, to do his/ her responsibilities. There are 4 competencies required to be a lecturer; pedagogic competence, attitude competence, social competence and professional competence which are gained through professional education. Each competency can be measured by several indicators that show the ability from many aspects.

If it relates to learning management system in University of Melbourne, it is obvious that lecturers' paedagogic competence holds the significant position. Further, this article will discuss more about pedagogic competence especially the learning management without ignoring the other competencies behind in order to increase the learning quality in Islamic higher education.
The educational awareness about the importanceoflecturers' paedagogiccompetence especially on learning management is growing since Paulo Freire critisized the passivee learning management badly. He said it was like banking educational; the lecturers deposited knowledge and experinces to learners, then the learners received, took notes, and filed all the information as documentation. This educational model is kind of colonialism on learners since it blocked their creativity and talent.

Friere's critics made monumental dan revolusioner changes in educational field in early 21st century. Various model and educational approaches were offered to develop effective learning process which learners as the centre actors. One of effective approaches was offered by constructivisme as the development of cognitive psychology(Piaget, 1971). This group thought that learning was to develop various strategies to take notes and get more information. Learners must be active to get information, while the teachers become partner during the process of getting information and understanding the lesson.

To adopt and adapt Learning management systems running in University of Melbourne, lecturers must be able to develop themselves as designer, teacher, assesor, and facilitator for learners. The lecturers should prepare everything related to the learning process before. Thus, the lecturers will be ready to teach and manage the class democratically.

After knowing the learners' characers, the lecturers are expected to be able to manage learning cycles such as designing the learning, developing learning indicator, determining the method and suitable approachment, using technology in the learning process, and evaluating the instruments used in the learning process. The lecturers also need to increase the learning theories and learning principles and able to develop the curriculum of the subject. Those skills will make the teacher able to use 
the assesment and evaluate the learning as the reflection to improve the learning quality.

The use of learning activities term makes us realize that the main focus of learning process in classroom is students (student-centered learning). This paradigm is developed into paradigm of sophisticated learning approach, replaces traditional school habit which tends to put teacher as a focus of activities (teachercentered learning). Generally, teacher is active and dominant in learning process, meanwhile, students become passive participants.

As a center of learning, students should be more active to build an understanding, skills, and certain attitude (active learning). Students' activities become a center because learning is an active process in which students use their thought to build an understanding (constructivism approach).

It is no longer enough for the students only to memorize knowledge transferred by the teacher (transfer of knowledge). The potentiality of human brain is not only used to memorize but also to analyze information gained and to build new understandings. This term is known as an information analysis skill. By activating the students in learning process, they are trained to use their thinking ability, the more the higher, the more students are able to think abstract and complex things so they can find new ideas. Therefore, the essence of active learning does not lie at students' physical activities. Silent students analyzing a text for example, it does not mean that they are passive learners because they use all their thinking ability to do analysis and make conclusions. Learning activities like this will make students able to think innovatively and creatively.

The use of different activities of teaching and learning process enables the teacher to serve students' different learning styles in a classroom because students' learning styles are different to each other. Physically, students' learning styles are different because they tend to be strong in audible, visual, tactile, connative perception or combination of all. Mobility tendency of students are also different. Some students like silent learning but the others can concentrate studying when they move freely. Physical comport with consumption pattern can differ students' learning styles. There are some students can learn when they eat or drink something but the other students cannot. The choice of time also determines learning styles. There are some students who like to learn in the morning, at the day time, and even in the evening. In addition, temperature at certain time also influences students' learning styles as well as environment. Some students like to learn in silent situation but the others learn while listening to the music. Some students like to learn brightened by sunshine or lamp but the other learn brightened by bulbs. Some students like to learn at cool place but the other like to learn at warm place. Some students feel comfortable when they study in a neat atmosphere but the others do not.

All aspects explained above determine certain learning styles. The variation of learning activities has bigger possibility in facilitating student's different learning styles. It can be compared with a teaching and learning process dominated by lecture, only audible students like it. The variation of learning activities is also believed to produce strong memory for the students. A study reported the comparison between learning style with information presentation is remembered in a long term of time.

To make learners fun to study is the basic of energizing learners to manage their own learning. However, we need to remember that the parameter of fun learning is not only judged based on the crowd but also based on learners' joy in doing assignment and the spirit to continuously elaborate the knowledge and skill which are learned (joyful learning). Thus, the lecturer should try to make learning and classroom environment conducive for learners

That is the sophisticated learning paradigm that should be developed in classes 
at Islamic higher education. Without changing traditional way of teaching, active learning process cannot run.

In this pedagogic competency, lecturers are expected to be well prepared to begin learning process. It can be seen from their instructional designs. At the beginning, the lecturers have to determine learning objectives that they want to reach. Then, they determine learning topics that they have to develop into teaching material, references, assignment, and scoring system.

Like in University of Melbourne, learning processin Islamic higher education is conducted into three phases: face to face attendance, tutorial, and independent learning. Face to face attendance is often done in Islamic higher education that two other phases. Even tough there are tutorial and independant learning phases, their forms are not as maximal as in University of Melbourne.

Face to face attendance in classroom should be done. This pattern is usually a routine meeting between lecturer and students in classroom. In this phase, a lectures teaches and facilitates the learning in a form of class discussion to explore ideas and clarify ambigue answers. To activate students in the classroom, a lecturer has to give students opportunity to ask questions and discuss the learning topics. All lecturers of Islamic higher education have to be familiar to apply active learning approach, so it give students chance to participate more in the classroom. The students' involvement in this learning process reflects to their $75 \%$ attendace on average.

To support intensed interaction, a lecturer can make students' attendance at library as scoring component. Their attendance at library has something to with activities of book loan for the need of assignment assigned by the lecturer.

The lecturers in University of Melbourne make tutorial session as reinforcement material in classroom. At this stage, discussion is done in small group discussion out of classroom and lead by senior chosen by the lecturer which is usually taken from graduate program. The purpose of tutorial session is to reinforce and digging up the lesson given by the lecturer in classroom through group discussion. On line discussion is another way to interact among learners or lecturer. This makes the learners do collaborative learning and independent learning in conducive learning space which are available in every college corner. Learners' activities are continued in several events such as; weekly exam, weekly reading, and weekly assessment. The weekly activity can be done more effectively into class presentation and roundtable discussion. All learning process is done strictly based on the rules of minimum $75 \%$ attendance.

To see the learning process in University of Melbourne, paradigm of changing from conventional-traditional method to creativeinnovative method offered by Jhonson (2002) has made University of Melbourne as one of the best universities in the world. The paradigm is shown in the table below.

\begin{tabular}{|l|l|}
\hline $\begin{array}{c}\text { Conventional-Traditional } \\
\text { Learning Pattern }\end{array}$ & \multicolumn{1}{|c|}{$\begin{array}{c}\text { Creative-innovative } \\
\text { New Learning Pattern }\end{array}$} \\
\hline $\begin{array}{l}\text { Method/ strategy which is } \\
\text { commonly used is lecturing/ } \\
\text { teacher center }\end{array}$ & $\begin{array}{l}\text { Various strategy/ methods will } \\
\text { be used. It depends on material, } \\
\text { learners' condition, and media } \\
\text { availability }\end{array}$ \\
\hline $\begin{array}{l}\text { The learning is focused on } \\
\text { teacher centre }\end{array}$ & $\begin{array}{l}\text { The learning is focused on } \\
\text { learners }\end{array}$ \\
\hline $\begin{array}{l}\text { Learners are passive } \\
\text { information receipients }\end{array}$ & $\begin{array}{l}\text { Learners are involved actively } \\
\text { during the learning process }\end{array}$ \\
\hline Learners study individually & $\begin{array}{l}\text { Learners study in pairs, groups, } \\
\text { discussion, presentation, and } \\
\text { giving feedback }\end{array}$ \\
\hline $\begin{array}{l}\text { The learning is too abstract and } \\
\text { theoretical }\end{array}$ & Learning is based on real life \\
\hline $\begin{array}{l}\text { Learners' behavior is based on } \\
\text { habit }\end{array}$ & $\begin{array}{l}\text { Learners' behavior is based on } \\
\text { self consciousness }\end{array}$ \\
\hline $\begin{array}{l}\text { Skills are developed based on } \\
\text { training }\end{array}$ & $\begin{array}{l}\text { Skills are developed based on } \\
\text { understanding }\end{array}$ \\
\hline $\begin{array}{l}\text { Teaching and learning process } \\
\text { are measured through formal } \\
\text { test }\end{array}$ & $\begin{array}{l}\text { Learning outcomes is measured } \\
\text { through process, effort, } \\
\text { output, performance, behavior, } \\
\text { documentation, test, etc }\end{array}$ \\
\hline $\begin{array}{l}\text { Teaching and learning process } \\
\text { happens only in classroom }\end{array}$ & $\begin{array}{l}\text { Learning happens in many } \\
\text { places }\end{array}$ \\
\hline Etc & Etc \\
\hline
\end{tabular}


Through mainstreaming of active learning, changing the paradigm of conventional learning to be more creative and innovative can be done by Islamic higher education. It has already been started by some Islamic higher education but this mainstreaming have to be more encouraged so all Islamic higher education can take advantages of this new paradigm.

From some models of learning management system in University of Melbourne, there are some models cannot be applied but hopefully it can be applied as tutorial pattern even though it is hard to do it in Islamic higher education in Indonesia. At least, lecturers can do weekly reading and weekly assessment. The results of these two activities can be reported in class presentation and roundtable discussion activities.

From aspect of learning quality control, some universities are still waiting for the right momentum to do learning evaluation by using student-feedback questionnaire technique. If there is any, implementation of this technique in Islamic higher education is not massive. It just fulfils the instruments without having follow up. In University of Melbourne and other uiversities in Europe, this technique has been the mainstream in increasing learning quality. The lecturers who gain negative feedback from students will follow up these findings by having workshop of increasing competency held by university.

From aspect of the use of the result of the research, Islamic higher education can learn much from University of Melbourne. Phenomena of social research which becomes research theme in Islamic higher education is often ended in documents of research institute. Ideally, socialization of the results of these researches becomes agenda every campus to present them in seminars or symposiums so that the learning process will happen there. Dissemination of knowledge in seminar room not only helps the development of science but also overcomes problems of social community.
In fact, learning based ICT is a big problem to be applied in Indonesian Islamic higher education. The use of ICT in campus is not maximal enough due to lack of hardware and experts. Therefore, trainings based on ICT become importance agenda for all lecturers in Islamic higher education.

\section{CONCLUSION}

Based on the description above, it can be concluded that the pattern of learning in the Islamic universities in Indonesia which is still dominated by conventional learning model with teacher-centered approach needs to be reconstructed through contemporary learning model with student-centered approach. One of the efforts to construct this paradigm is doing bench-marking against universities in Australia, like Melbourne University, particularly on the study of their Learning Management System.

There are some important notes related to learning strategy developed at Melbourne University. First, it enhances student active learning through a variety of learning experiences, such as on-line discussion (collaborative learning), weekly readings, weekly exams, weekly assignments (independent learning), class presentation, and round table discussion. Second, learning managementsystem at Melbourne University has been running well with an integrated system of ICT which enables the lecturers to communicate their courses and enables the students to interact dynamically with the tasks, lectures, and other students.

Finally, the reflection on student learning models at Melbourne University is important to consider to step up toward the need for rethinking and reconstructing the learning methodology in Islamic higher education. This can be an inspiration and alternative model for us to design the new learning approach and environment that promote active learning pedagogy in Islamic higher education in Indonesia. 


\section{REFERENCES}

Bruner, J., (2008): Toward a Theory of Instruction, Cambridge, Harvard University press

Davis, Barbara, Gross (1993): Tools For Teaching. San Francisco, Jossey-Bass Publishers

DePorter, Bobbi (et.al). (1999): Quantum Teaching: Orchestrating Student Success, Boston, Allyn and Bacon.

Dimyati dan Mudjiyono (1999): Belajar dan Pembelajaran. Jakarta, Rineka Cipta

Elaine B. Jhonson (terj. Ibnu Setiawan) (2006): Contextual Teaching and Learning. Bandung, Mizan Media Utama.

E. Mulyasa (2008): Standar Kompetensi dan Sertifikasi Pengajar. Bandung, PT. Remaja Rosda Karya: Bandung.

Fraser, Kym (1996): Student Centered Teaching: The Development and Use of Conceptual Frameworks. Jamison Centre, Australia, Higher Education Research and Development Society of Australia.

Gardner, Howard (1993): Multiple Intelligences; Theory in Practice. New York, Basic Books.

Hamalik, Oemar (2006): Pendidikan Pengajar Berdasarkan Pendekatan Kompetensi. Jakarta, PT. Bumi Aksara.

Johnson, D.W., Johnson, R.T., \& Smith, K.A. (1991): Active Learning: Cooperation in the College Classroom, Endina, MN: Interaction Book Company.

Johnson, D.W. \& Smith, K.A. (1992): Active Learning: Cooperation in College Clasroom, Edina, MN, Interati Book Company.

Lozanov, Georgi (1978): Suggestology and Outlines of Suggestopedy. New York, Gordon \& Breach.

McNergney, Robert F. and Carrol A. Carrier (1981): Teacher Develovement. New York, MacMillan Publishing co. In.

Me Keachie, W.J. (1986): Teaching Tips: A Guidebook for the Beginning College Teacher. Lexington, MA, Heath.

Priere, Paulo (2001): Pedagogi Pengharapan. Yogyakarta, Kanisius.

(terj. Agung Prihantoro) (1999):

Politik Pendidikan: Kebudayaan, Kekuasaan, dan Pembebasan. Jogjakarta, Pustaka Pelajar.

Pike, R. (1989): Creative Training Techniques Handbook. Minneapolis, MN, LakewoodBooks.

Pollio, H.R. (1984): What Student Think About and Do In College Lecture Classes. Teaching Learning Issues. No. 53. University of Tennesses.

Ramsden, P. (1992): Learning to Teach in Higher Education, New York, Routledge.

Renner, Peter (1994): The Art of Teaching Adults, Vancouver, Training Associates.

Rose, Colin \& J. Nicholl Malcolm (1997): Accelerated Learning For The 21st Century, London, Judy Piatkus.

Silberman, Melvin L. (1996): Active Learning; 101Stratigies to $T$ each any Subject. Boston, Allyn and Bacon.

Suwarna (2006): Pengajaran Mikro Pendekatan Praktis Menyiapkan Pendidik Profesional, Yogyakarta, Tiara Wacana.

Sutherland, Peter (1997): Adult Learning. London, Kogan Page.

Uno, Hamzah B. (2008): Perencanaan Pembelajaran. Jakarta, Bumi Aksara.

Usman, Moh. Uzer (1993): Belajar Mengajar. Bandung, Remaja Rosda Karya.

Piaget, J. (1951): Psychology of Intelligence. London, Routledge and Kegan Paul.

Wenger, Win (200), Beyond Teaching \&Learning. Gaithersburg, Renaissance.

Whitton, Diana, (et. al.) (2010): Learning for teaching:Teaching for Learning. Australia, National Library of Australia Cataloguing.

Zaini, Hisyam dkk. (2002): Strategi Pembelajaran Yogyakarta, Center For Teaching Staff Development (CTSD). 